\title{
Acoustic survey for estimating density of anchovy schools in the south sea of Korea
}

\author{
Eunbi Min \\ School of Marine Technology, Chonnam National University, Republic of Korea \\ Eun-A Yoon \\ National Institute of Fisheries Science, Republic of Korea \\ Sung-Tae Kim \\ National Institute of Fisheries Science, Republic of Korea \\ Seong Yong Moon \\ Republic of Korea \\ Hyun Woo Kim \\ Department of Marine Biology, Pukyong University, Republic of Korea
}

Southeast Sea Fisheries Research Institute, National Fisheries Research \& Development Institute, Tongyeong,

See next page for additional authors

Follow this and additional works at: https://jmstt.ntou.edu.tw/journal

Part of the Fresh Water Studies Commons, Marine Biology Commons, Ocean Engineering Commons, Oceanography Commons, and the Other Oceanography and Atmospheric Sciences and Meteorology Commons

\section{Recommended Citation}

Min, Eunbi; Yoon, Eun-A; Kim, Sung-Tae; Moon, Seong Yong; Kim, Hyun Woo; Salim, Shelly; Kang, Taejong; and Hwang, Doo-jin (2021) "Acoustic survey for estimating density of anchovy schools in the south sea of Korea," Journal of Marine Science and Technology. Vol. 29: Iss. 2, Article 4.

DOI: 10.51400/2709-6998.1081

Available at: https://jmstt.ntou.edu.tw/journal/vol29/iss2/4

This Research Article is brought to you for free and open access by Journal of Marine Science and Technology. It has been accepted for inclusion in Journal of Marine Science and Technology by an authorized editor of Journal of Marine Science and Technology. 
Acoustic survey for estimating density of anchovy schools in the south sea of Korea

Authors

Eunbi Min, Eun-A Yoon, Sung-Tae Kim, Seong Yong Moon, Hyun Woo Kim, Shelly Salim, Taejong Kang, and Doo-jin Hwang 


\title{
Acoustic Survey for Estimating Density of Anchovy Schools in the South Sea of Korea
}

\author{
Eunbi Min ${ }^{a}$, Eun-A Yoon ${ }^{b}$, Sung-Tae Kim ${ }^{b}$, Seong Yong Moon ${ }^{c}$, Hyun Woo Kim ${ }^{\text {d }}$ \\ Shelly Salim ${ }^{\text {a }}$, Taejong Kang ${ }^{a}$, Doojin Hwang ${ }^{a, *}$

\footnotetext{
a School of Marine Technology, Chonnam National University, Republic of Korea

${ }^{\mathrm{b}}$ National Institute of Fisheries Science, Republic of Korea

${ }^{c}$ Southeast Sea Fisheries Research Institute, National Fisheries Research \& Development Institute, Tongyeong, Republic of Korea

${ }^{\mathrm{d}}$ Department of Marine Biology, Pukyong University, Republic of Korea
}

\begin{abstract}
Anchovies (Engraulis japonicus) are one of the most commercially important fish species in the Republic of Korea. To estimate the biomass of anchovies, acoustic surveys were conducted around Namhae, Tongyeong, and Geoje in May, June, and August 2019. The acoustic surveys were carried out by using the National Fisheries Research and Development Institute's TAMGU No. 10 (R/V), the line of survey was approximately $200 \mathrm{Km}$ and the survey area was $476 \mathrm{Km}^{2}$. The investigation system used was a $200 \mathrm{kHz}$ split beam-type scientific echosounder (EK80, Simrad, Norway). The acoustic data collected was analyzed using a post-processing sound analysis software (Echoview V 9.0, Echoview Software Pty Ltd, Australia). The parameters from Kang et al. (2015) were applied to the fish school detection algorithm to extract the anchovy schools at a single frequency. The NASC (Nautical Area Scattering Coefficient) of the anchovies was high in Namhae during May and in the coatal waters off Namhae and Tongyeong during June. In August, the NASC of the anchovy schools was lower than in May and June with similar values in all survey areas. The NASC value by depth was high, especially between the depth of 30 and $50 \mathrm{~m}$. The monthly density of anchovy schools were estimated at $4.89 \mathrm{~g} / \mathrm{m}^{2}$ $(C V=46.5 \%)$ in May, $4.56 \mathrm{~g} / \mathrm{m}^{2}(\mathrm{CV}=28.0 \%)$ in June and $0.17 \mathrm{~g} / \mathrm{m}^{2}(\mathrm{CV}=23.1 \%)$ in August.
\end{abstract}

Keywords: Anchovy, Acoustic estimates, Echosounder, South Sea

\section{Introduction}

$\mathrm{T}$ he anchovy (Engraulis japonicus) is a surface migratory fish species belonging to the herring (Clupeiformes) order, anchovy (Engraulidae) family that lives in the temperate waters of the coast. Anchovies move as a school and they are distributed throughout South Korea. The total production of coastal fisheries in South Korea is approximately 1 million tons, and among them, anchovies account for about 190,000 tons (19\%), making them, commercially, an important fishery resource. The total production of anchovies is mainly caught through anchovy boat seine fisheries $(58 \%)$ and other fisheries, such as, offshore stow nets $(12 \%)$, stationary nets $(8 \%)$, etc 2018 data [23]. Most of the anchovy production is caught off the south coast, where the currents with different properties, namely the Tsushima Current, the East Korea Warm Current, and the South Korean Coastal Water mix, thus supplying rich nutritional salts and food organisms and providing spawning and breeding grounds for anchovies, which lead to a suitable fishing ground environment [4]. The production of anchovies was more than 230,000 tons per year during 2006-2015, however, it has

Received 21 May 2020; revised 19 September 2020; accepted 15 October 2020. Available online 21 May 2021.

* Corresponding author.

E-mail address: djhwang@chonnam.ac.kr (D. Hwang). 
plummeted to approximately 140,000 tons in 2016, the anchovy production could not recover and continued to decline until 2018 [23]. This situation is believed to be related to the recent high temperature phenomenon in the sea that caused the anchovy fishing grounds in the coastal waters fail to form properly, leading to the decrease in the production volume. Therefore, the prediction of anchovy stocks is necessary for the sustainable resource management of anchovies.

The previous studies of anchovy characteristics distributed on the south coast, such as the distribution of anchovies' eggs and larvae $[2,19,22,34]$ and the estimation of anchovies' resources [3,14,20], were research tasks carried out during March to August, the time when the eggs and larvae of anchovy usually live.

In the previous studies, the resource estimation of anchovies on the south coast were undertaken by using a scientific fish school detector, however, it was difficult to identify the fish species using the current fish school detector. Therefore, in this study, it was attempted to estimate the resource by using the information of fish species obtained from the catches and other information from nets, fishing gear, and so on.

Recent studies using e-DNA techniques that allow species to be identified through environmental genes in the seawater are as follows: species identification and distribution of marine habitats $[7,11,27]$, study on species diversity (Díaz Ferguson et al., 2014, Kelly RP et al., 2014, Lacoursière-Roussel et al., $2016[36,37,38])$, experiments to estimate the resource volume using environmental genes $[6,24,25]$, the correlation between e-DNA concentration and fish size [28]. The e-DNA technique is cost- and time-effective to identify the fish species and to analyze the fish distribution and density because this method does not require the collection of marine organisms and minimizes artificial stress to the marine environment. Moreover, the higher the target fish species' dominance in the target waters, the more effective the resource evaluation.

Therefore, if both surveys using scientific fish school detectors and environmental genes analysis using e-DNA techniques are performed, the e-DNA techniques can provide the information of fish species to solve the fish species identification problems of the fish school detectors; then by comparing and analyzing the distribution and density of the measured fish species in each survey, an effective fishery resource evaluation can be achieved.
In this study, the distribution characteristics of anchovy schools and the relationship between the marine environment characteristics and anchovy schools based on acoustic data were analysed and examined by using the acoustic method, the e-DNA method, and the Opening-Closing net collection technique on the collected data during May, June, and August 2019 around Namhae, Geoje, and Tongyeong on the south coast.

\section{Material and method}

\subsection{Survey area}

The acoustic survey was conducted during May 22nd 23rd (first survey), June 18th 19th (second survey), and August 23rd-24th (third survey), 2019, using the National Fisheries Research and Development Institute's TAMGU No. 10 (25 Ton) to obtain the distribution and the biomass of anchovy schools living in the coastal waters of Namhae, Geoje, and Tongyeong, the main fishing grounds of anchovies. The survey transects were mainly Namhae, Geoje, and Tongyeong and a total of eight transects were designed using the following equation (1)[1].

$D O C=\frac{N}{\sqrt{A}}$

In this equation, $\mathrm{N}$ is the length of the survey transect and A is the survey area. Equation (1) is the basis to determine the feasibility of the survey transect's range when designing the survey transect in the area of the survey for efficient resource measurement and the value of DOC (Degree of Coverage) should not be less than 6 . The length of the survey transect in the sea area was about $200 \mathrm{Km}$ and the survey area was $476 \mathrm{Km}^{2}$ (as also shown in Fig. 1). Generally, the acoustic survey transects are designed in parallel lines or zig-zag form. The coastal waters from Namhae, covering Tongyeong until Geoje, of this survey represent a wide survey area at a given time, and while keeping the DOC value to be within the range of above 6 , the survey transect was designed in the zig-zag form in order to perform a time-saving and efficient investigation.

In addition, as shown in Fig. 1, collection surveys using CTD (DIVER, Eijkelkamp, Netherlands) were conducted together on the same day as the acoustical survey. For e-DNA surveys, 16 survey points $(\Delta)$ were selected and on each point, seawater environmental genes samples were collected. The eDNA surveys were conducted once per month during April to October 2019, for a total of 7 surveys. The CTD was only used on e-DNA survey during 


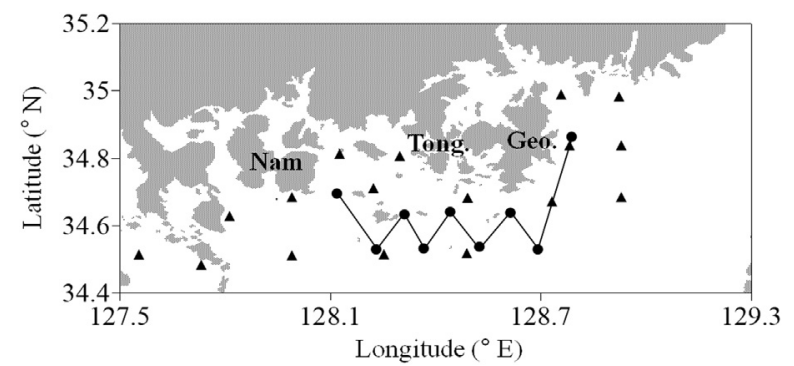

Fig. 1. Study area for the acoustic survey on the south coast in May, June, \& October 2019 (Line: Survey line of acoustic and Indicates Transect 1 from the line on the right, $\bullet$ : Survey points of CTD, $\mathbf{\Delta}$ : Survey points of e-DNA).

May, June, and August, to match the period of the acoustic surveys of this study.

\subsection{The system and measurement method of the acoustic surveys}

The sound system consists of a split-beam scientific fish school detector (EK80, Simrad, Norway) with frequencies of $200 \mathrm{kHz}$ and a four-divisional sound wave transceiver that can detect the location of fish, a GPS device (NF560, Samyung, Korea), and a laptop. The acoustic survey was conducted after the scientific fish school detector system was calibrated (Table 1) using a calibration tool in a common water tank (W $5 \mathrm{~m} \times \mathrm{L} 5 \mathrm{~m} \times \mathrm{H} 5 \mathrm{~m}$ ) filled with seawater. At the survey site, the transducer, one of the components of the scientific fish school detector equipment, was placed at a depth of $1 \mathrm{~m}$ and installed at the lower end on one side of TAMGU No. $10(\mathrm{R} / \mathrm{V})$ by using the prepared fixtures. In addition, the WBT (Wide Band Transceiver), GPS, external power supply, laptop, etc. were installed in the cabins of the survey vessels and the measurement preparation was completed by connecting the transducer cables to the WBT. After that, the acoustic survey was carried out by sailing through the designated survey transect, maintaining a vessel

Table 1. System parameters of scientific echo sounder (EK 80, Simrad) for calibration.

\begin{tabular}{ll}
\hline Calibration setting & Value \\
\hline Frequency $(\mathrm{kHz})$ & 200 \\
Major A-xis 3 dB beam angle $\left(^{\circ}\right)$ & 9.12 \\
Minor A-xis $3 \mathrm{~dB}$ beam angle $\left(^{\circ}\right)$ & 7.04 \\
Salinity $(\mathrm{ppt})$ & 31.00 \\
sound speed $(\mathrm{m} / \mathrm{s})$ & 1529.42 \\
temperature $\left({ }^{\circ} \mathrm{C}\right)$ & 24.70 \\
transducer gain $(\mathrm{dB})$ & 25.52 \\
transmitted power $(\mathrm{W})$ & 105 \\
transmitted pulse length $(\mathrm{ms})$ & 0.512 \\
two way beam angle $(\mathrm{dB}$ re $1 \mathrm{sr})$ & -20.70 \\
\hline
\end{tabular}

speed at 6 to 7 knots, and collecting the sound data. Underwater acoustic measurements were performed as follows. The WBT calculates the electrical signal, generates acoustic signals called 'pings', and sends the signals underwater through the transducer. The transmitted signals are then reflected by the individual fish, fish schools, the seabed, etc. in the target range and the reflected signals are received as echoes by the transducer. The received echoes are converted to digital format through filtering and amplification and stored as RAW files on the laptop's hard disk. Data on acoustic measurement locations are continuously received from the connected GPS and collected together with the acoustic data. The parameters of the sound system applied in this survey are shown in Table 2.

\subsection{Acoustic data analysis}

The completely collected and stored acoustic data (RAW files) in the survey area were analyzed using underwater sound processing software (Echoview V9.0, Echoview Software Pty Ltd, Australia). The order of data processing was, first, all the surface noises generated around the transducer during sailing were removed from the RAW file and then the seabed area was separated from the underwater area. The seabed separation was performed by applying the function to automatically distinguish the boundary line between the seabed and the water layer. However, considering the case of demersal fish being recognized as the seabed, part of the seabed lines was created manually.

Even though the surface noise and the seabed have been separated from the acoustic data, since the acoustic data of the underwater areas were collected from the sea, various noises from the marine environment, the vessel itself, electrical equipment, etc. can also be collected simultaneously. These noises have to be removed because they cause errors to the marine organism's density analysis of the underwater area. The software's filter functions were used to remove two types of noise. The impulse noise is caused by interference with other sound equipment and the noise's shape appeared as short and irregular vertical lines on the

Table 2. System parameters of scientific echo sounder (EK 80, Simrad) for acoustic survey.

\begin{tabular}{ll}
\hline Echosounder parameters & Value \\
\hline Frequency & $200 \mathrm{kHz}$ \\
Beam type & split beam \\
Power & $105 \mathrm{~W}$ \\
Pulse width & $0.512 \mathrm{~ms}$ \\
Ping rate & $1 \mathrm{ping} / \mathrm{s}$ \\
\hline
\end{tabular}


echogram. Transient noise is caused by interference with other electrical equipment and its shape appeared as long and regular vertical lines on the echogram [32]. Each noise can be removed by the impulse noise removal function and the transient noise removal function, in which the removal method is by specifying each noise's threshold value at the same depth in the echogram, identifying excessive noise above the noise's threshold value, and removing them. In this study, impulse noise removal was performed before transient noise removal.

The sound data after noise elimination contains only the acoustic information about the marine life and, to extract the information of a single species of fish among the data, fish species identification is required. The analysis was performed using the morphological characteristics of the fish schools $[14,21]$ since anchovies have a habit of forming and moving in schools. In this study, the anchovy schools were automatically identified using the software's School Detect function (Fig. 2) and the anchovy schools' forms were identified using [14] anchovy fish school detection parameters (Table 3).

The areas identified as anchovy schools were saved using the Bitmap function and the saved areas were extracted as the anchovy schools data using the Mask operators.

\subsection{Opening-closing net and e-DNA survey}

In order to obtain the information about the species of fish inhabiting the survey area, an Opening-

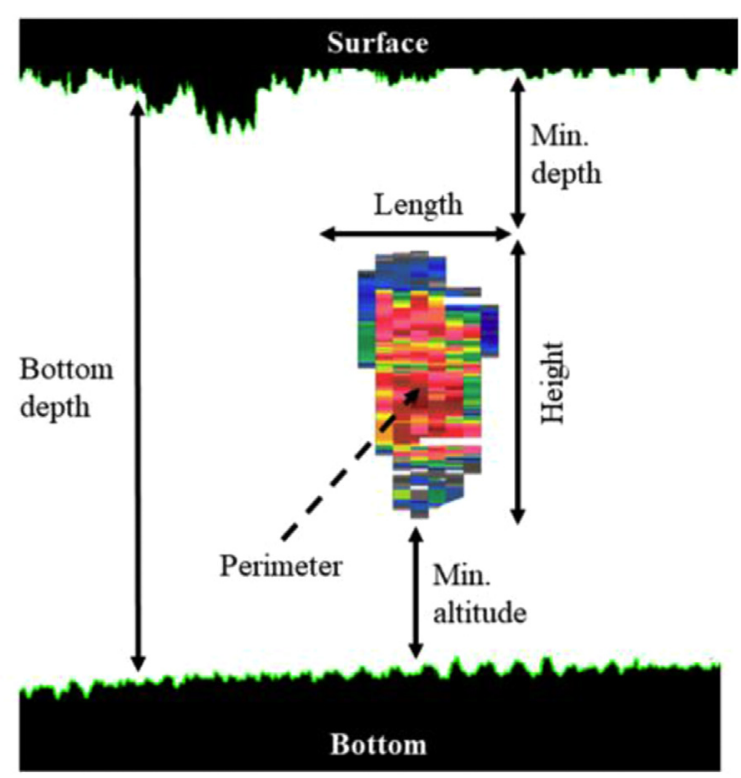

Fig. 2. Morphological characteristics displaying anchovy schools' detection.
Table 3. System parameters of the scientific echo sounder (EK 80, Simrad) for anchovy school detection.

\begin{tabular}{ll}
\hline Setting & Value \\
\hline Minimum total school length $(\mathrm{m})$ & 3.0 \\
Minimum total school height $(\mathrm{m})$ & 1.6 \\
Minimum candidate length $(\mathrm{m})$ & 3.0 \\
Minimum candidate height $(\mathrm{m})$ & 1.6 \\
Minimum horizontal linking distance $(\mathrm{m})$ & 2.0 \\
Maximum horizontal linking distance $(\mathrm{m})$ & 5.0 \\
Distance mode & GPS distance \\
\hline
\end{tabular}

Closing net (diameter $80 \mathrm{~cm}$, mesh $330 \mathrm{um}$ ) was used, with a maximum depth of $60 \mathrm{~m}$ from the surface layer and the samples were collected at a speed of 3 knots per survey points, towed in a diagonal line, for a duration of approximately $10 \mathrm{~min}$. The collected samples were put in a sampling container and transported to the laboratory in an ice box. A three-dimensional anatomical microscope was used to identify the fish species and the ocular micrometer attached to the microscope was used to measure the size of the anchovies.

Moreover, in this study, comparing the distribution and density of anchovies was attempted using both acoustic data and e-DNA analysis data. The eDNA refers to the DNA released from the organisms into the environment, which generally consisted of the sequences of the genes. The analysis of the organism's DNA in the sampled environment was performed by using base sequence analysis method, that is, by using the base sequence of the species primer and the short probe to supplement the deficiencies in a certain base sequence. Using the inherent individual genetic information, such as blood, skin tissue, scales, excrement, eggs, etc. of the marine organisms underwater, the species can be identified and its density can be estimated. The eDNA investigation method was to collect $2.5 \mathrm{~L}$ of seawater using a collection container at the survey points, to put it in an ice box, and transport it to the laboratory. The collected samples were filtered using a filter with a $0.45 \mu \mathrm{m}$ mesh and the genomic DNA in the sample was extracted using DNeasy Blood \& Tissue Kit (Qiagen, Germany). Then, the DNA was then tested and quantified using trace spectrophotometer and the distribution of anchovy DNA among the total e-DNA detected was analyzed. In addition, to compare the anchovies' temporal and spatial distribution from e-DNA analysis and acoustic analysis, we selected five points of the most similar e-DNA survey points to the acoustic survey transects and analyze the correlation between anchovies' density at each location.

Image analysis software (Image Pro Plus V 10.0, Media Cybernetics Ltd, USA) was used to compare 
distributions, and the area according to scale was calculated at each survey point and then converted to absolute values. Absolute density values of acoustic and e-DNA surveys were analyzed using statistical software (IBM SPSS Statistics V 25.0, IBM corp, USA). In correlation analysis, sampling was based on the area, which is a hierarchical variable. In addition, the significance test identified significant differences between acoustic and environmental gene densities as per Spearman, which could identify the correlation between hierarchy variables.

\subsection{Density estimation method of anchovy using the acoustic method}

In this study, to estimate the distribution and density of anchovy schools using sound, only the echo signals of anchovy schools are extracted from the acoustic signals collected on the monthly surveys using the Echoview software and displayed on the echogram.

By the interval of 0.5 n.mile, the EDSU (Elementary Distance Sampling Unit) is integrated and Volume backscattering strength (SV) is obtained. SV is a nonlinear data, in order to analyze the temporal and spatial distribution characteristics and the biomass of fish schools [29], it is converted into a linear form that is Nautical Area Scattering Coefficient (NASC). The NASC is a value referring to 1 square nautical mile and the equation to convert $\mathrm{SV}$ to NASC is shown in equation (2).

$N A S C=4 \pi 1852^{2} \int_{r_{1}}^{r_{2}} S_{V} d r$

As shown in equation (3), the linear form of NASC values calculated at interval 0.5 n.miles can be quantified and the density of the fish group $(\rho, \mathrm{g} /$ $\mathrm{m}^{2}$ ) can be calculated by means of a density formula.

$N A S C=\rho \cdot T S$

Therefore, Equation (4) is used to calculate the density of a single anchovy species by dividing the average NASC value by the backscattering cross section value $(\sigma)$ of the anchovy schools and multiplying it by a weight. The right side of equation (4) is the density estimation equation that takes into account $\sigma$ and the size-weight relationship $(\omega)$.

$\rho=\left(\frac{N A S C}{\sigma}\right) \cdot \omega=\frac{a L^{b}}{4 \pi 10^{\left(\frac{T S}{10}\right)}} \cdot N A S C$

The $\sigma$, which is the conversion factor (CF) to obtain density, and the $\omega$ are as shown in equations
(5) and (6), respectively. Here, the collected data from the Opening-Closing net conducted together with the acoustic survey was used in the size-weight equation of anchovies. Also, equation (7) is obtained from the ex-situ TS equation by [12].

$\sigma=4 \pi 10^{\left(\frac{\mathrm{TS}}{10}\right)}$

$\omega=a L^{b}$

$T S_{200 \mathrm{kHz}}=20 \log (T L)-69.1($ Kangetal., 2009$)$

The mean fish school density $(\bar{\rho})$ of the entire survey area is shown in equation (8), as the weighted average of the mean density data for each survey transect.

$\bar{\rho}=\frac{\sum_{i=1}^{N} \overline{\rho_{i}} \cdot n_{i}}{\sum_{i=1}^{N} \cdot n_{i}}$

The $\overline{\rho_{i}}$ is mean density of the $i$ th survey transect, $n_{i}$ is the number of EDSU of the $i$ th survey transect, and $\mathrm{N}$ is the number of survey transects.

\section{Results}

\subsection{The biological characteristics of anchovies}

In order to estimate the density of anchovies using acoustic method, the information about the size and weight of anchovies inhabiting that certain sea area is required. The data about the size and weight of the anchovies were provided through measurement results of collection survey using an OpeningClosing net, which was conducted together with the acoustic survey of this study. This data is used to analyze the anchovies' length frequency distribution (Fig. 3). The monthly size distribution range of the collected anchovies was $11-15.0 \mathrm{~cm}$ in May, $12-15.0 \mathrm{~cm}$ in June and $10-13.0 \mathrm{~cm}$ in August, whereas the average size was $12.3 \mathrm{~cm}$ in May, 12.0 $\mathrm{cm}$ in June and $11.4 \mathrm{~cm}$ in August. In addition, the size-weight equation for anchovy collected in May, June and August was $\mathrm{W}=0.0051 \mathrm{TL3} .0734\left(\mathrm{R}^{2}=\right.$ 0.79), as shown in Fig. 4.

\subsection{Distribution of anchovy schools by shape and size}

In May, June, and August 2019, the distribution of anchovy schools were analyzed by shape and size measured by the scientific fish school detector in the survey area (Fig. 5).

As shown on the monthly echogram, in May, the results showed a narrow, long vertical form of 


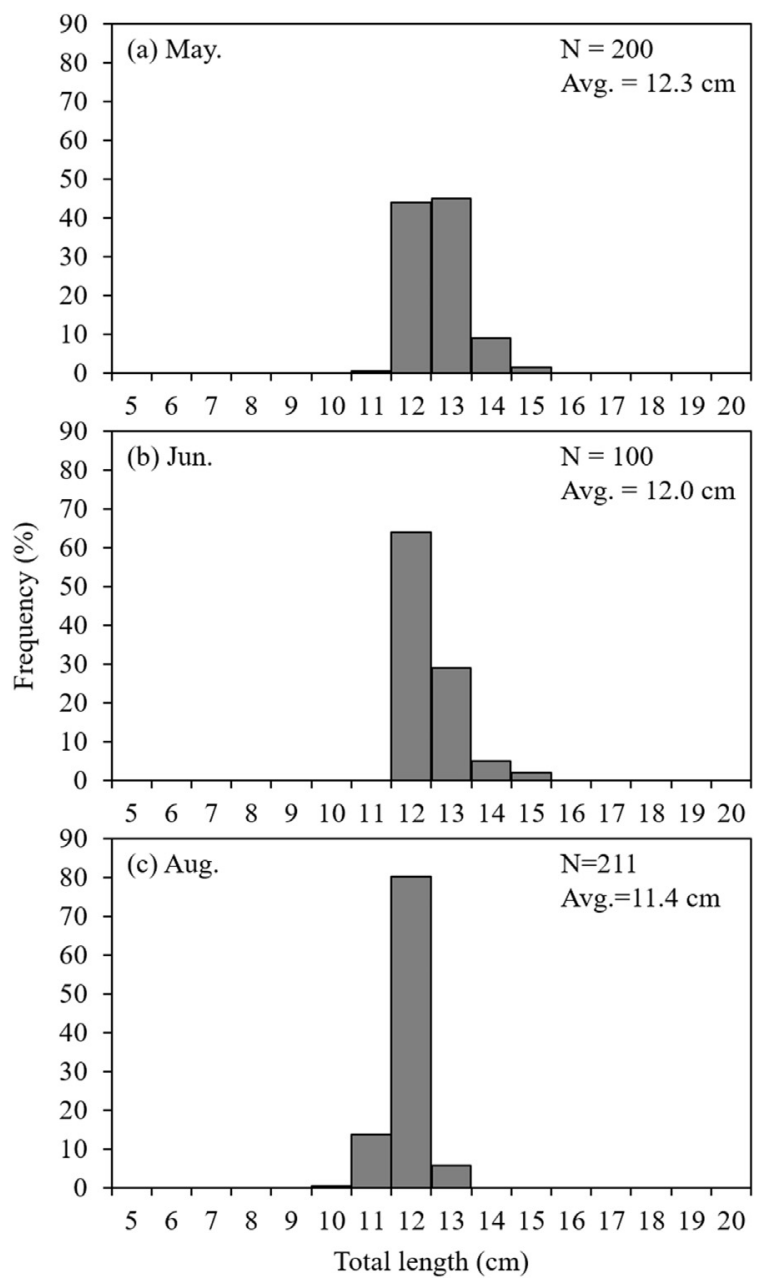

Fig. 3. Length frequency distribution of anchovies collected from the south coast in 2019.

anchovy schools distributed as patches across the entire water levels. In June, the results showed a narrow, long vertical form of anchovy schools concentrated as large fish schools distributed throughout the water level. In August, the results

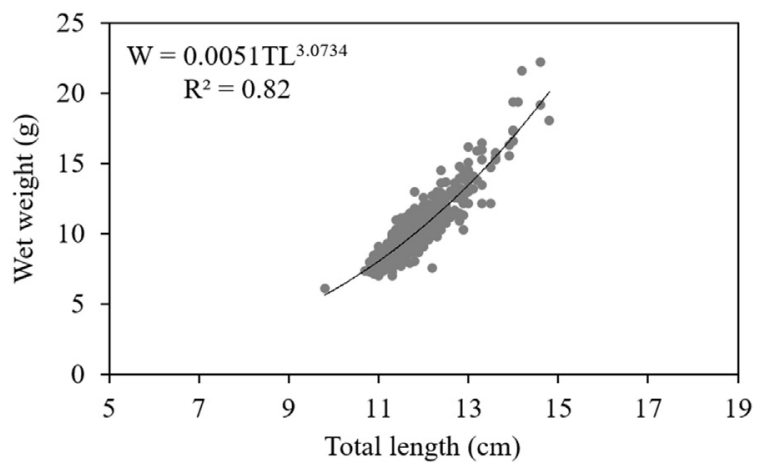

Fig. 4. Length-weight relationship of anchovies collected from the south coast in 2019.

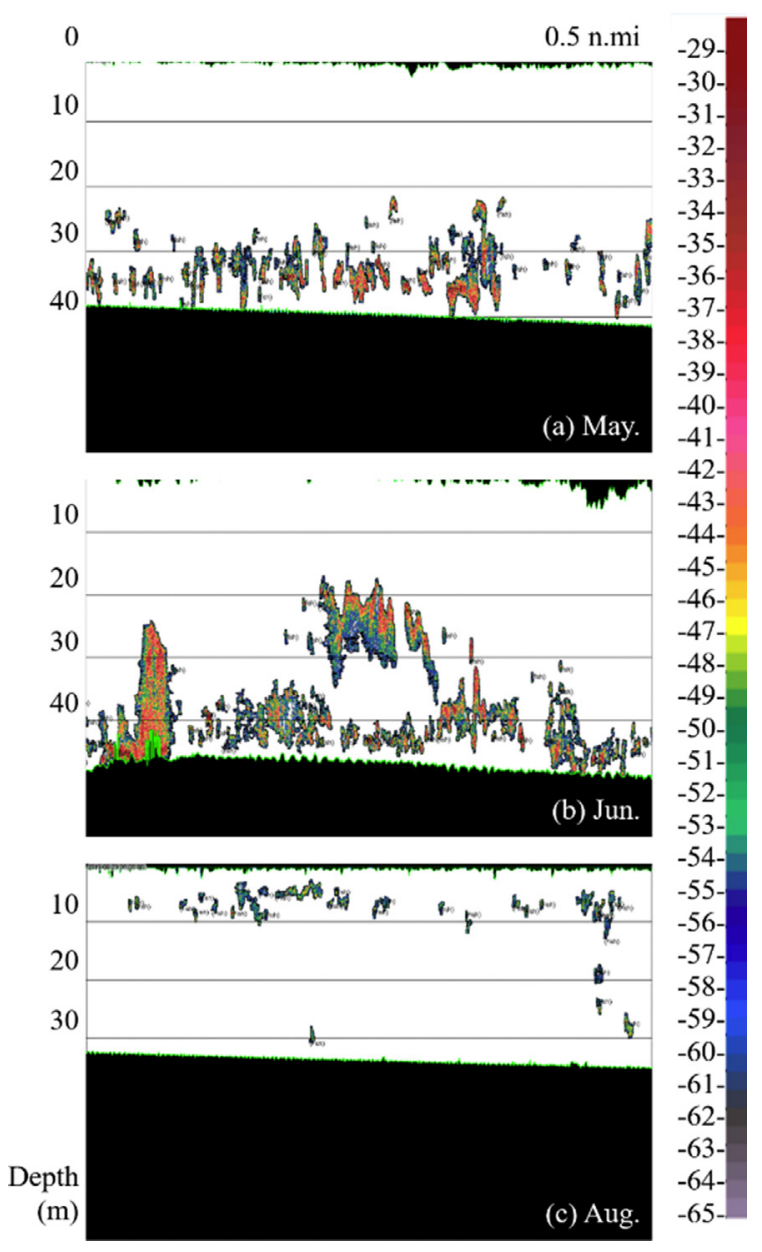

Fig. 5. Characteristics of anchovy schools by size in the acoustic survey area in 2019 (Part of monthly echogram).

showed no high acoustic scattering strength detected as fish schools and, based on the low acoustic scattering strength, only individual fish were detected.

\subsection{The distribution of anchovy schools by depth}

The vertical distribution by depth was analyzed through acoustic data from anchovy schools collected in May, June, and August 2019 (Fig. 6). As shown in Fig. 8, May and June showed high NASC values at depths of $10-60 \mathrm{~m}$, with the highest NASC values at $30-50 \mathrm{~m}$ depths. In general the NASC values in August were very low and NASC values were low at $10-20 \mathrm{~m}$ in depth.

\subsection{Temporal-spatial distribution and density estimation of anchovies}

The acoustic data collected in May, June, and August 2019, after noise removal and anchovy 


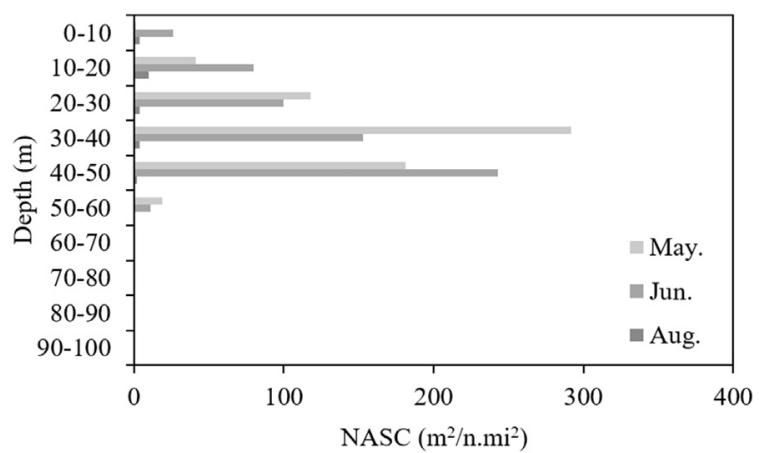

Fig. 6. Mean NASC of anchovy schools by depth measured by acoustic survey on the south coast in May, June, \& August 2019.

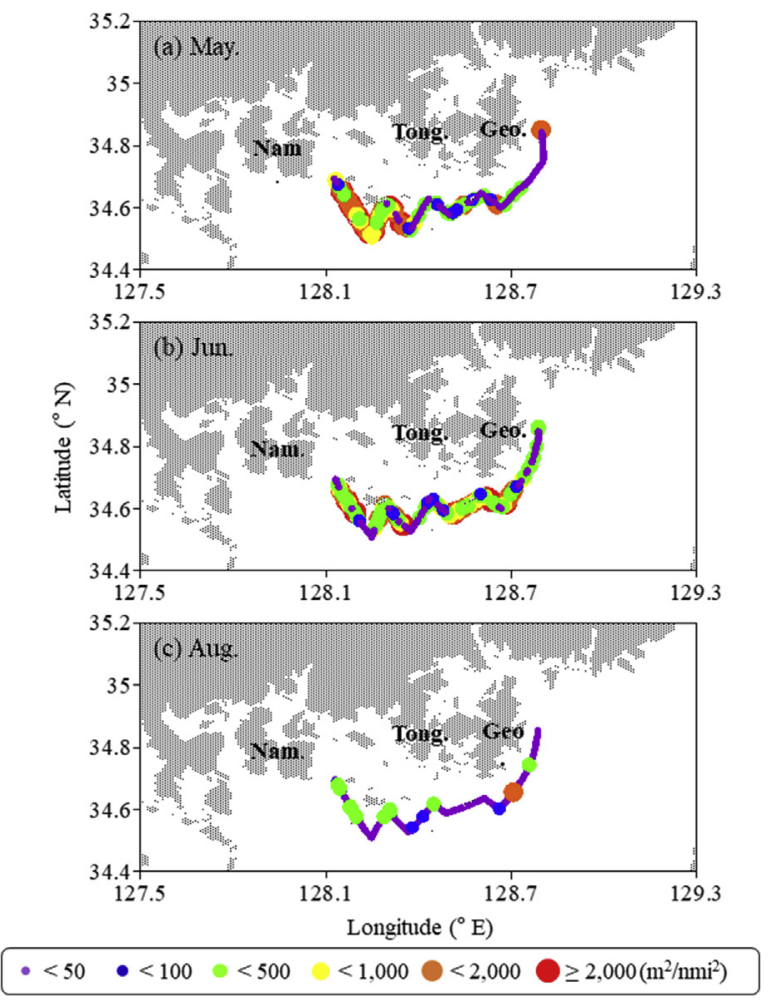

Fig. 7. Spatial-temporal distribution of anchovy schools using nautical area scattering coefficient (NASC, $\mathrm{m}^{2} / \mathrm{nmi}^{2}$ ) data with $0.5 \mathrm{nmi}$ interval.

schools identification, showed the extracted NASC values of anchovies and they are expressed in terms of temporal and spatial distribution in the survey area (Fig. 7).

The distribution of anchovies in May showed a high density only on the western side of the survey areas and the density went lower on the eastern side. In general, June's survey results showed a high density and August's survey results showed a low density.

The average NASC value of the anchovies per survey transects in May was the highest at $569.1 \mathrm{~m}^{2}$ /

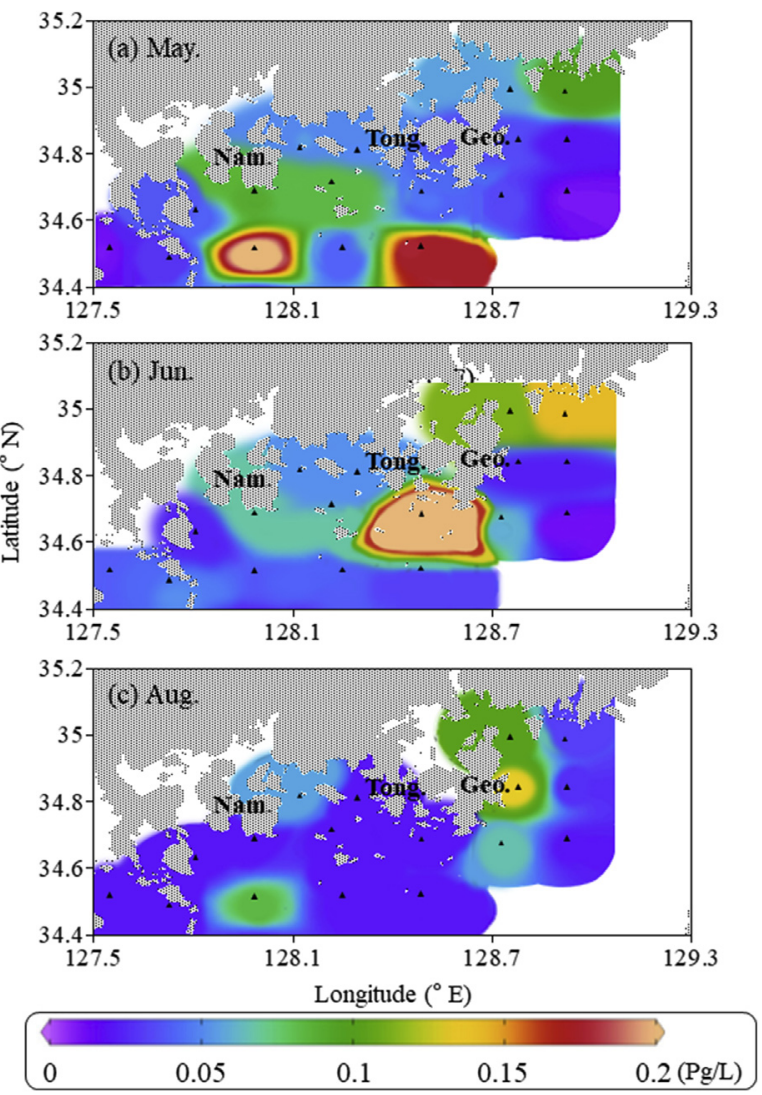

Fig. 8. Relative abundance of Engraulis japonicus DNA in the southern coastal waters of Korea.

n.mi ${ }^{2}$ on transect 5 and the lowest at $110.4 \mathrm{~m}^{2} / \mathrm{n} . \mathrm{mi}^{2}$ on transect 2. In June, it was the highest at 11165.2 $\mathrm{m}^{2} / \mathrm{n} . \mathrm{mi}^{2}$ in transect 2 and the lowest at $433.7 \mathrm{~m}^{2} /$ n.mi ${ }^{2}$ in transect 3. In August, it was the highest at transect 2 with $11,165.2 \mathrm{~m}^{2} / \mathrm{n} \cdot \mathrm{mi}^{2}$ and the lowest at transect 3 with $433.7 \mathrm{~m}^{2} / \mathrm{n} \cdot \mathrm{mi}^{2}$. In addition, the average monthly density was $4.89 \mathrm{~g} / \mathrm{m}^{2}$ in May, 4.56 $\mathrm{g} / \mathrm{m}^{2}$ in June and $0.17 \mathrm{~g} / \mathrm{m}^{2}$ in August (Table 4).

In this study, in order to compare and analyze the distribution and density of anchovy schools using

Table 4. Estimating the density of anchovies by acoustic survey on the south coast in May, June, \& August 2019.

\begin{tabular}{|c|c|c|c|c|c|c|}
\hline \multirow[t]{2}{*}{ Transect } & \multicolumn{2}{|c|}{ May } & \multicolumn{2}{|c|}{ June } & \multicolumn{2}{|c|}{ August } \\
\hline & $n_{i}$ & NASC & $n_{i}$ & NASC & $n_{i}$ & NASC \\
\hline 1 & 39 & 69.9 & 39 & 348.0 & 41 & 34.6 \\
\hline 2 & 10 & 201.5 & 9 & 2708.5 & 12 & 0.9 \\
\hline 3 & 14 & 242.6 & 15 & 981.2 & 27 & 5.4 \\
\hline 4 & 8 & 54.1 & 10 & 205.7 & 12 & 15.5 \\
\hline 5 & 16 & 85.8 & 16 & 56.6 & 26 & 16.0 \\
\hline 6 & 15 & 1494.3 & 16 & 804.4 & 22 & 36.7 \\
\hline 7 & 15 & 1044.5 & 15 & 465.9 & 19 & 9.5 \\
\hline 8 & 29 & 1694.1 & 30 & 649.0 & 49 & 37.7 \\
\hline$\sum_{i=1}^{N} \cdot n_{i}$ & 146 & & 150 & & 202 & \\
\hline $\begin{array}{l}\text { Mean density } \\
\left(\rho, \mathrm{g} / \mathrm{m}^{2}\right)\end{array}$ & 4.89 & & 4.56 & & 0.17 & \\
\hline
\end{tabular}


sound, an e-DNA survey was conducted. The relative distribution of anchovy DNA among the total eDNA detected at the survey points in the wider survey area is presented as the temporal and spatial distribution (Fig. 8).

The monthly distribution of anchovies showed the highest density in the western part of the survey area in May and the density increased as it went to the open sea. June's results showed a highest density in the eastern part of the survey area, with the highest density around the coast. In general, the density was low in August.

The location of the survey area for correlation analysis is marked as A to E in Fig. 9 and the results are shown in Fig. 10. In the density comparison using image analysis, the overall distribution was the largest in June, followed by May and August. The results with the highest density in June and lowest density in August were the same in acoustic and e-DNA surveys. However, the distribution by area shows that there are differences (Table 5). Density differences are understood to be caused by the absence of sound and e-DNA surveys on the same day. The results of the monthly correlation analysis between acoustic and e-DNA surveys are shown in Table 6 . Since the monthly density of acoustic and e-DNA surveys was calculated based on the scale bar of density, the correlation coefficient was set as per Spearman. The correlation

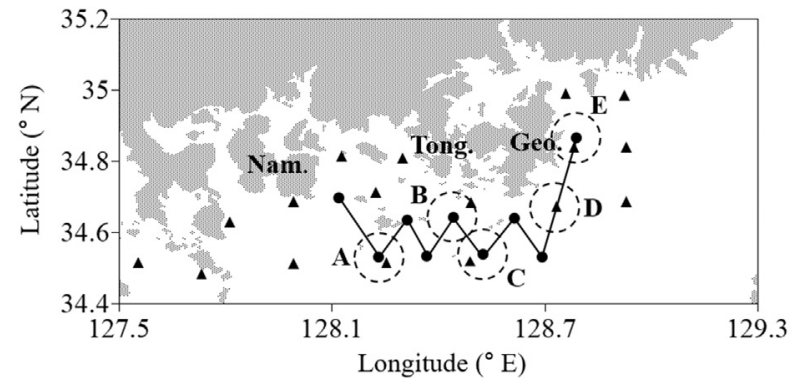

Fig. 9. Areas $(A-E)$ for comparison between density estimated by acoustic surveys and e-DNA testing.

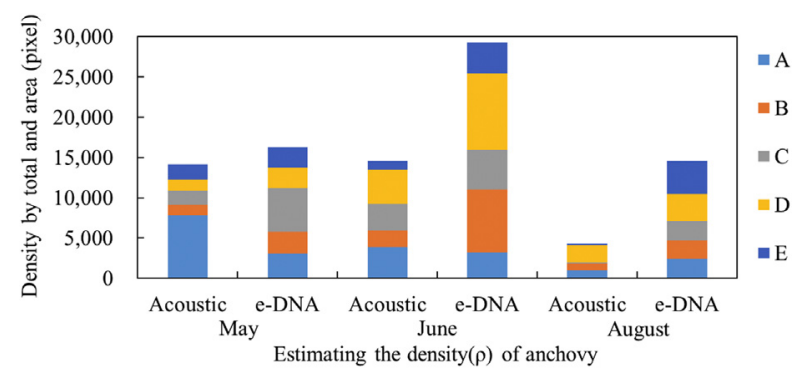

Fig. 10. Anchovy density by area of acoustic and e-DNA surveys expressed using image analysis. between the acoustic density and environmental DNA density in the areas of A to E in May was 0.870, indicating a significant level of 0.05 or higher, indicating that there was no difference. The correlation between June and August was 0.505 and 0.437 respectively, showing no significant difference (Table 6).

\section{Analysis and conclusion}

In this study, the relationship between anchovy schools and distribution characteristics by month, depth, and form of fish schools were identified and the density was estimated, based on the marine environment of anchovy schools living in southern coastal waters, using an acoustic method in May, June, and August 2019. In addition, the structureweight relationship equation of anchovies is required to estimate density and it was obtained by examining the Opening-Closing net and also by comparing and analyzing the density of anchovies by e-DNA surveys, a method of resource evaluation that can identify fish species and estimate density, in the same survey area.

Anchovies are known to have a suitable spawning water temperature of $15-26{ }^{\circ} \mathrm{C}$ [33], but the recent decrease in anchovy production suggests that the surface water temperature has soared up to $30^{\circ} \mathrm{C}$ in 2016 and that the anchovies have not been properly formed along the coast [34]. Suggested that the water temperature does not only affect the production but also other environmental conditions such as food and water currents. Also, researches on anchovies inhabiting the south coastal regions have been conducted since the 1990s by research on eggs and larvae, trawling, and scientific fish school detectors, indicating that the south coast is a major sea area that requires periodic observation as the main spawning and breeding grounds of anchovies Lee et al $1996[2,3,5,13,14,19,20,22,34,39]$.

In this study, the water temperature measured during the survey period was $16-25{ }^{\circ} \mathrm{C}$ and 19 28 ${ }^{\circ} \mathrm{C}$ in May and June, respectively, and these results are similar to the suitable spawning water temperature known in [33], while August showed the highest water temperature of $24-27{ }^{\circ} \mathrm{C}$. The distribution density of anchovies over the months showed a high density in May and June, when the suitable spawning water temperature was available and the lowest density in August when the water temperature was the highest $[4,30]$, Lee et al 1996, and [26], all of whom performed studies collected from the south coast, confirmed a high density of the appearance of anchovy eggs and larvae in May to July when the water temperature did not exceed 
Table 5. Anchovy density by acoustic and e-DNA survey analyzed through image analysis.

\begin{tabular}{|c|c|c|c|c|c|c|}
\hline \multirow{2}{*}{$\frac{\text { Monthly\&Survey }}{\text { Density area }}$} & \multicolumn{2}{|l|}{5} & \multicolumn{2}{|l|}{6} & \multicolumn{2}{|l|}{8} \\
\hline & Acoustic & e-DNA & Acoustic & e-DNA & Acoustic & e-DNA \\
\hline A & 7,817 & 3,068 & 3,886 & 3,180 & 1,034 & 2,366 \\
\hline B & 1,352 & 2,735 & 2,014 & 7,819 & 790 & 2,366 \\
\hline C & 1,718 & 5,381 & 3,297 & 4,956 & 173 & 2,366 \\
\hline $\mathrm{D}$ & 1,356 & 2,552 & 4,259 & 9,499 & 2,148 & 3,362 \\
\hline E & 1,928 & 2,552 & 1,117 & 3,834 & 161 & 4,112 \\
\hline Total of density (Pixel value) & 14,170 & 16,289 & 14,573 & 29,287 & 4,305 & 14,570 \\
\hline
\end{tabular}

Table 6. The significant probability of correlation (Spearman) coefficient for anchovy density using image analysis.

\begin{tabular}{llll}
\hline Source & May & June & August \\
\hline Significant Level $(\mathrm{p})$ & 0.870 & 0.505 & 0.437 \\
\hline $\mathrm{P}<0.05$. & & &
\end{tabular}

$25^{\circ} \mathrm{C}$. The study of Choo and Kim 1998 [35] showed a decline in the appearance of anchovy eggs and larvae in August when the water temperature was over $25{ }^{\circ} \mathrm{C}$. Therefore, through this survey and prior research, the monthly distribution of anchovies along the south coast was scattered during the spring season (March to May) and during the summer (May to July). The density was high as the anchovies remained in coastal areas without movement during the early growth of life cycle.

Moreover, the monthly density distribution showed high density only in the western part of the survey area in May, a high density in June, and a low density in August. As such, the monthly density varies depending on the characteristics of the water flow, which is distributed along the southern coastal waters. The anchovy is a fish species that lives in surface currents and coastal turbulence and the movement of the fish schools are highly affected by the seawater current. Southern coastal cities during the spring and summer experience the Tsushima Warm Current, the East Korean Warm Water, along with rain and the stream of water flow. The anchovy density is distributed as the area is moving west to east in the survey area, according to the monthly current.

The monthly distribution of anchovies shows the highest distribution on the lower layers of $30-50 \mathrm{~m}$, with the overall distribution of anchovies in depths from 10 to $60 \mathrm{~m}$ in May and June. Meanwhile, few fish schools were detected to be anchovies in August, and the small distribution of low acoustic scattering strengths at $10-20 \mathrm{~m}$ depths was analyzed to be a distribution of small fish schools. The form of anchovy distribution was characterized by patches in the form of narrow, vertically long fish schools and the vertical distribution patterns of anchovies in the preceding study of the form characteristics of anchovies [15], Kim et al., 1999 [40] showed the same results as those of fish schools shown in this study.

In addition, the spatial distribution and density of anchovy schools inhabiting the survey area were compared using both acoustic and environmental DNA. To compare the results of the two surveys, it was noted that the density distribution in the five areas identified did not show any significant difference. In addition, pixel values of density through image analysis showed slightly different trends by area, but the locations of high density were similar. It is thought that the survey should be conducted on the same day to estimate the density of future acoustic and e-DNA surveys. Therefore, considering the overall density of e-DNA and of the acoustic surveys in the overall survey area, the high density location was similar, thus the purpose of this study was to identify the tendency of density distribution in anchovy groups and to consequently obtain basic data from the surveyed areas.

\section{Acknowledgements}

This work was supported by a grant from the National Institute of Fisheries Science (R2021034). This research was a part of the project titled "Research center for fishery resource management based on the information and communication technology" (2021, grant number 20180384), funded by the Ministry of Oceans and Fisheries, Korea.

\section{References}

[1] Aglen A. Random errors of acoustic fish abundance estimates in relation to survey grid density applied. FAO Fish Rep 1983;300:293-8.

[2] Cha BY, Yang WS, Kim JI, Jang SI, Chu EK, Park JS. Spawning density and recruitment of Japanese anchovy, Engraulis japonica in the southern sea of Korea in 2007. Kor J Ichthyol 2007;20(3):190-7.

[3] Choi SG, Kim JY, Kim SS, Choi YM, Choi KH. Biomass estimation of anchovy (Engraulis japonica) by acoustic and Trawl surveys during spring season in the southern Korean waters. J Kor Soc Fish Res 2001;4:20-9.

[4] Choo HS, Kim DS. The effect of variations in the Tsu-shima warm currents on the egg and larval transport of anchovy in the Southern Sea of Korea. J Kor Fish Soc 1998;31(2):226-44.

[5] Choo HS. The variations of Oceanic conditions and the Distributions of eggs and larvae of anchovy in the southern sea of Korea in summer. J Kor Fish Soc 2002;35(1):77-85. 
[6] Doi H, Inui R, Akamatsu Y, Kanno K, Yamanaka H, Takahara T. Environmental DNA analysis for estimating the abundance and biomass of stream fish. Freshwater Biol 2017;62(1): 30-9.

[7] Doi H, Takahara T, Minamoto T, Matsuhashi S, Uchii K, Yama-naka H. Droplet digital PCR outperforms real-time PCR in the detection of environmental DNA from an invasive fish species. Environ Sci Technol 2015a;49(9):5601-5608.

[11] Ikeda K, Doi H, Tanaka K, Kawai T, Negishi JN. Using environmental DNA to detect an endangered crayfish Cambaroides japonicus in streams. Conserv Genet Res 2016;8(3): 231-4.

[12] Kang DH, Cho SH, Lee CW, Myoung JG, Na J. Ex situ target-strength measurement so $\mathrm{f}$ Japanese anchovy (Engraulis japonicus) in the coastal North west Pacific. ICES J Mar Sci 2009;66(6):1219-24.

[13] Kang MH, Choi SG, Hwang BK. Acoustic characteris-tics of Anchovy schools, and visualization of their connection with water temperature and salinity in the Southwestern Sea and the West southern Sea of South Korea. J Korea Soc Fish Technol 2014;50(1):39-49.

[14] Kang MH, Seo YI, Oh TY, Lee KH, Jang CS. Esti-mating the biomass of anchovy species off the coast of Tongyeong and Yeosu in South Korea in the spring and winter of 2013 and 2014. J Kor Soc Fish Technol 2015;51(1):86-93.

[15] Kang NH, Yoon GD, Choi YM, Kim JK. Hydroa-coustic investigations on the distribution characteristics of the anchovy at the south region of East Sea. Bull Kor Soc Fish Tech 1996;32(1):16-23.

[19] Kim JI, Kim JY, Choi YK, Oh HJ, Chu EK. Distribu-tion of the anchovy eggs associated with coastal frontal structure in southern coastal waters of Korea. Kor J Ichthyol 2005;17(3):205-16.

[20] Kim JI, Yang WS, Oh TY, Seo YI, Kim ST, Hwang DJ, et al. Acoustic estimates of anchovy bio-mass along the Tongyoung-Namhae coast. J Korean Fish Soc 2008;41(1):61-7.

[21] Kim ZG, Choi YM, Hwang KS, Yoon GD. Study on the acoustic behaviour patten of fish school and species identification. Bull Kor Soc Fish Tech 1998;34(1):52-61.

[22] Ko JC, Seo YI, Kim HY, Lee SK, Cha HK, Kim JI. Distribution characteristics of eggs and Larve of the anchovy Engraulis japonica in the Yeosu and Tongyeong coastal waters of Korea. Kor J Ichthyol 2010;22(4):256-66.

[23] KOSIS. Fishery production trend investigation, by fishery and Each variety statistics. 2019. Retrieved from, http://www. kostat.go.kr. [Accessed 16 April 2019].

[24] Lacoursière-Roussel A, Côté G, Leclerc V, Bernatchez L. Quantifying relative fish abundance with eDNA: a promising tool for fisheries management. J Appl Ecol 2016a;53(4): 1148-57.

[25] Lacoursière-Roussel A, Rosabal M, Bernatchez L. Estimating fish abundance and biomass from eDNA concentrations: varia-bility among capture methods and environmental conditions. Mol Ecol Res 2016b;16(6):1401-14.

[26] Lee CI, Kim HJ. Effect of temperature on anchovy catch and laver production in the eastern part of the South Sea of Korea. J Environ Sci 2007;16:897-906.

[27] Miya M, Sato Y, Fukunaga T, Sado T, Poulsen JY, Sato K. MiFish, a set of universal PCR primers for metabarcoding environmental DNA from fishes: detection of more than 230 sub-tropical marine species. Royal Soc Open Sci 2015;2(7): 150088.

[28] Mizumoto $H$, Urabe $H$, Kanbe $T$, Fukushima M, Araki $H$. Establishing an environmental DNA method to detect and estimate the biomass of Sakhalin taimen, a critically endangered Asian salmonid. Limnology 2018;19(2):219-27.

[29] Myriax. Echoview 4.50.50. Tasmania, Australia: Myriax software Pty Ltd; 2008

[30] Park JH, Lee JH. In relation to the formation of fishing ground and the fluctuation of fishing condition of anchovy, Engraulis japonica, catched by anchovy drag net. Bull Kor Fish Tech Soc 1991;27:238-46.

[32] Ryan TE, Downie RA, Kloser RJ, Keith G. Reducing bias due to noise and attenuation in open-ocean echo integration. ICES J Marine Sci 2015;72:2482-93.

[33] Tsuruta Y. Life history strategy of Japanese anchovy. Nippon Suisan Gakkaishi 2001;67:1133-4.

[34] Yoo JT, Kim YH, Song SH, Lee SH. Characteristics of egg and larval distributions and catch changes of anchovy in relation to abnormally high sea temperature in the South Sea of Korea. J Kor Soc Fish Ocean Technol 2018;54(3):262-70.

[35] Choo HS, Kim DS. The effect of variations in the Tsushima warm currents on the egg and larval transport of anchovy in the Southern Sea of Korea. J Korean Fish Soc 1998;31(2): 226-44.

[36] Kelly RP, Port JA, Yamahara KM, Crowder LB. Using environmental DNA to census marine fishes in a Large Mesocosm. PLoS ONE 2014;9(1):1-11.

[37] Lacoursière-Roussel A, Côtè G, Leclerc V, Bernatches L. Quantifying relative fish abundance with eDNA: apromising tool for fisheries management. J Appl Ecol 2016;53: 1148-57.

[38] Díaz Ferguson EE, Moyer GR. History, applications, methodological issues and perspectives for the use environmental DNA (eDNA) in marine and freshwater environments. Rev Biol Trop 2014;62(4):1273-84.

[39] Lee EK, Yoo JM, Kim S, Lee YC. Vertical distribution of anchovy, Engraulis japonicuslarvae in the Korea strait. Korean J Ichthyol 1996;8(2):47-56.

[40] Kim DS, Kim JS. Relation between chlorophyyll-a and catch of anchovy by the lift net in the coastal waters yosu bull. Fish Sci Inst Yosu Nat'l Univ 1999;8:1-8. 